\title{
Heart Failure Patients' Experiences in Communicating with Nurses during Hospitalization
}

\section{Dewi Mastuti ${ }^{1}$, Ayu Fitriana Hapsari ${ }^{1}$, and Beti Kristinawati}

${ }^{1}$ Student, School of Nursing, Faculty of Heath Science, Universitas Muhammadiyah Surakarta, Indonesia

${ }^{2}$ Departement of Medical Surgical Nursing, School of Nursing, Faculty of Health Science, Universitas Muhammadiyah Surakarta, Indonesia

\section{Abstract}

Background: Heart functional damage and hospitalization undertaken by patients can cause phsyical and psychological problems. During treatment, patients communicate with nurses. Communication that occurs can affect phsyical and psychological conditions.Objective: The objective of this research was to explore the experience of heart failure patients in communicating with nurses during hospitalization.Design:

Corresponding Author:

Dewi Mastuti

dewimastuti.ums@gmail.com

Received: 22 September 2019

Accepted: 4 October 2019

Published: 10 October 2019

Publishing services provided by

Knowledge E

(c) Dewi Mastuti et al. This article is distributed under the terms of the Creative Commons

Attribution License, which permits unrestricted use and redistribution provided that the original author and source are credited.

Selection and Peer-review under the responsibility of the ICHT 2019 Conference Committee. The study design was qualitative phenomenology with data collection done by doing in-depth interviews with 12 participants selected by purposive sampling. All of the data was analyzed using Colaizzi Analysis Content.Result: The study produced five themes, namely: 1). Therapeutic communication is applied by nurses when treating heart failure patients 2). Familiarity can create a good interpersonal relationship between nurse and patient 3). An effective communication is one of the patient's satisfactions during hospitalization 4). Fast response is one of the satisfactions for patients with heart failure 5). Collaborating is done by the nurse to overcome the symptoms that arise. Conclusions: Communication is needed by heart failure patients to overcome physical and psychological problems.

Keywords: Heart Failure, Therapeutic-Communication

\section{Introduction}

Heart failure is one of the disease that can't spread as the number one of disease every year that happens in the developed countries though developing countries [1]. Heart failure is a chronicle phase that can cause heart failure breakdown and cause many symptoms, so there are many symptoms that experienced by the heart failure patients [2]. Heart failure is one of the health problems that increasingly rise with increasingly of human age that happens in the developed countries and developing countries [3], basic Health Research (2013) heart failure patients most found with age around 
censor will change in the education acceptance. Information acceptance is influenced with increasingly with increasingly age, where young age will make easier accept the information than elderly will find difficulty to accept the information. Heart failure more many men patients instead women. Based on Hamzah (2016) the men have twice heart failure risker than women, this is related to hormone. Estrogen hormone on the women have effect to prevent the cardiovascular disruption with lowering of stress [4]. Most of hormonal factors can cause the women than the men, it happens because the women tend have not stable hormone than the men. So the women have the highest emotional characteristic [5]. The Anxiety is more likely to occur in women because women use more feelings when responding to all forms of changes that occur [5]. Patients who experience anxiety in cardiovascular disorders can be treated with healing therapeutic communication, interaction with clients is the stage where nurses do explore ability before dealing with clients [6]. Nurses are individuals who provide services to patients, patients' families, and the community, both sick and healthy. Which covers the entire process of human life. Nurses must have therapeutic communication skills aimed at facilitating relationships and mutual trust with clients to prevent illegal problems [7], Therapeutic communication can help clients clarify the feelings that are being thought about, can also reduce client anxiety. Communication training is the main point for improving nurses' communication skills with clients.

\section{Methods}

This research is a descriptive study with a qualitative method using a phenomenological design. The selection of research informants is purposive, namely the selection based on the objectives with the subject as an analysis unit that is deemed appropriate to the needs. The core informants in this study were heart failure patients who were hospitalized. Data collection was carried out with in-depth interviews with 12 heart failure patients who were hospitalized. Data analysis in this study uses thematic analysis from Brown and Clarke (2012). Thematic analysis is an analysis method used to identify, organize, present meaning into patterns of meaning (themes) through data. Data analysis was carried out with six thematic analysis stages as follows:

1) Recognize data

2) Initialize the code

3) Look for themes

4) Reviewing themes

5) Define the theme 
6) Write a report

\section{Results}

TABLE 1: Frequency Distribution of the Participants Based on Demographic Data.

\begin{tabular}{l|c|c|}
\hline Characteristics & Frequency & Percentage (\%) \\
\hline Gender & 3 & 25 \\
\hline Male & 9 & 75 \\
\hline Female & & \\
\hline Age & 3 & 25 \\
\hline 20-50 years old & 9 & 75 \\
\hline 50-69 years old & & \\
\hline Occupation & 5 & 41,6 \\
\hline Entrepreneur & 1 & 8,3 \\
\hline Entrepreneurship & 2 & 17,1 \\
\hline Labor & 4 & 33 \\
\hline Government Employees & & 33 \\
\hline Education & 1 & 81,6 \\
\hline Elementary School & 5 & 17,1 \\
\hline Junior High School & 2 & 3 \\
\hline Senior High School & & \\
\hline Scholar & & \\
\hline
\end{tabular}

The frequency distribution of heart failure patients based on age, sex, last education, occupation and income shows that of the 12 respondents with age categories, the majority are aged 50-69 years. Based on the sex category the majority of respondents were female. Based on the latest education the majority have a junior high school background. Based on the occupational category of the majority of entrepreneurs.

In the table above shows the results of the analysis based on Braun and Clarke formed six categories that have been narrowed down to five broad themes in order, including: 1). Therapeutic communication is applied by nurses when treating heart failure patients 2 ). Familiarity can create a good interpersonal relationship between nurse and patient 3). An effective communication is one of the patient's satisfactions during hospitalization 4). Fast response is one of the satisfactions for patients with heart failure 5). Collaborating is done by the nurse to overcome the symptoms that arise 
TABLE 2: Category \& theme.

\begin{tabular}{|c|c|}
\hline Category & Theme \\
\hline Communication pattern & $\begin{array}{l}\text { Therapeutic communication is applied by nurses when } \\
\text { treating heart failure patients }\end{array}$ \\
\hline Good interpersonal relationships & $\begin{array}{l}\text { Familiarity can create good interpersonal relationships } \\
\text { between nurses and patients }\end{array}$ \\
\hline $\begin{array}{l}\text { Patient satisfaction Providing } \\
\text { education provided by nurses is one } \\
\text { of the patient's satisfaction in service }\end{array}$ & $\begin{array}{l}\text { Effective communication is one of the patient's } \\
\text { satisfaction during hospitalization }\end{array}$ \\
\hline $\begin{array}{l}\text { Nurse response to patient } \\
\text { complaints }\end{array}$ & $\begin{array}{l}\text { Fast response is one of the satisfaction for heart failure } \\
\text { patients }\end{array}$ \\
\hline $\begin{array}{l}\text { he act of collaboration is carried } \\
\text { ut by nurses }\end{array}$ & $\begin{array}{l}\text { The act of collaboration is carried out by the nurse to } \\
\text { overcome the symptoms that arise }\end{array}$ \\
\hline
\end{tabular}

The experience of heart failure patients when communicating with nurses is based on the results obtained from 12 participants who said that nurses had good therapeutic communication, were polite, served with care and did not discriminate between patients. The application of this communication is carried out when the patient is hospitalized. The dimensions of the nurse's communication response can change the mindset of patients who have a positive attitude to the health of patients suffering from heart failure.

\section{Disscusion}

Theme 1. Therapeutic communication is applied by nurses when treating heart failure patients

Therapeutic communication is applied when nurses communicate to heart failure patients who are undergoing hospitalization. One of the actions of the nurse is polite, friendly, smooth communication and not using a rude tone to patients who are undergoing hospitalization. Participants' understanding of polite words were expressed by participants P1, P5 and P4, as well as patient-friendly expressed by participants P9, P5, $\mathrm{P} 2$ and the application of good communication was expressed by participants P11, P7 and P8. The following participant expressions:

"As long as there are nurses, there is nothing rude, no bitch ( $p 1)$ "

"All nurses speak softly" (p5) "'The tone of polite communication sis, do not use high notes (p4)"

As for the way the nurse is friendly to the patient makes the patient comfortable with the services provided. 
"E... good and friendly sis" (p4)"

"Friendly as a smile, and if there is a mistake not immediately angry "(p9)"

Good communication will be effective only through frequent use and practice, using good communication to patients who are being hospitalized will open the way for patients to tell about the experience of the illness suffered by the patient. The following participant statement:

"The communication is good, nurses never distinguish between patients. Alhamdulillah (p11) "

"The communication is good and the handlers are also good. the service is overall good and the doctor is also good (p7) "

"The communication is good and the service is also good (P8 patient's family)"

There is a relationship between the implementation of therapeutic communication with the level of satisfaction caused by the implementation of therapeutic communication properly, the patient feels comfortable and valued so that it will cause a sense of satisfaction in the patient. In accordance with Priyanto's theory, A (2012)

Theme 2 . Familiarity can create a good interpersonal relationship between nurse and patient

Interviews were conducted interpersonal ie between nurses and patients who had undergone hospitalization. This is done so that patients in providing data about the situation can be more open and the relationship between patients and nurses more familiar. So as a nurse can provide maximum service and in accordance with the needs of inpatients. From the above themes about the familiarity of nurses and: "Hehe, that is, the person is good ( $p 5)$ "

"Yes the nurse is good, sis, (p2)"

The high interpersonal communication of nurses will affect the high level of patient satisfaction (Hanafi and Richard, 2012)

Theme 3. An effective communication is one of the patient's satisfactions during hospitalization

From the above themes about good service expressed by participants $\mathrm{P} 10$ and P4, as well as the information disclosed by participants P6. The following participant expressions:

"Yes polite, yes it should be like that means that as a public service must be able to serve those served (p10)"

"friendly and serve it quite well (p4)"

"What we want to know will be explained in detail by nurses (p6) " 
Patient satisfaction with nurse officer communication is the level of feeling after comparing nurses' communication that is felt with the desired expectations of undergoing treatment Patient satisfaction is a level of feeling that arises as a result of the performance of health services obtained after patients compare what they expect

Theme 4.) Fast response is one of the satisfactions for patients with heart failure Communication nurses who ask patient complaints is an open attitude towards patients, there are questions asking patient complaints to make patients comfortable will tell what is being felt by patients. The patient expresses complaints of pain to drain the thought of his illness. From the above themes regarding complaints in patients expressed by participants P8 and P2. The following participant expressions: "When examined what the complaints were asked. (p8) "

"I usually ask what my complaints are, I'm the type of person who can't complain, I'm embarrassed if I want to complain (hehehe) I usually ask, what is the complaint still sick or not (p2) "

One of the factors that influence satisfaction in the service or provision of nursing care is communication of the procedures for delivering information provided by service providers and responding to complaints from patients and how patient complaints are quickly received by service providers, especially nurses in responding to patient complaints

Tema 5. Collaborating is done by the nurse to overcome the symptoms that arise

The patient feels tightness when there is no activity or activity. One of the causes of heart disease is tightness, the patient feels a sneeze until it continues to pass out immediately. From the above themes about the patient feeling tightness expressed by participants $\mathrm{P} 3$ and $\mathrm{P} 12$, as well as the management of heart failure expressed by participants P7. The following participant expressions:

"I have a heart disease, heart disease then feel tightness, dizziness, then faint (p3)" Giving oxygen can reduce the feeling of tightness that is being suffered by the patient. Severe or mild activities can also cause hiccups in patients with heart failure, such as activities to walk long distances or activities to climb stairs that are high enough can also cause the patient to feel a crunch in the chest or chest pain. The following participant's statement:

"Yes. When asked if a complaint feels tightness will be given oxygen or medicine (12)" 
"At first my chest ached to run the activity then I was taken to the doctor. OEN from doctor. OEN was referred here... then I was sentenced to have a real heart disease and then I was put in a ring (p7)"

\section{Conclusion}

Application of communication in patients with heart failure experienced by participants is based on theme 1 Interaction is applied when nurses treat patients with heart failure and theme 3 of good interaction is one of patient satisfaction. The handling of nurses to patient complaints through communication is dominated by the theme of 5 collaborative actions making one of the nurses' handling of complaints of patients with heart failure. The results of the research experience of heart failure patients in communicating with nurses while undergoing hospitalization. From the interviews, there were many participants who revealed that hospital treatment was very good and satisfied with the services provided by nurses through therapeutic communication when talking about complaints that were suffered. Need further research on communication in patients with heart failure who are hospitalized with more respondents to solve the problem.

\section{Acknowledgement}

The authors would like to thank their colleague for their contribution and support to the research. They are also thankful to all the reviewers who gave their valuable inputs to the manuscript and helped in completing the paper.

\section{Conflict of Interest}

The authors have no conflict of interest to declare

\section{References}

[1] Kemenkes, R. I. (2014). Infodatin: Situasi Kesehatan Jantung. Pusat Data dan Informasi Kementerian Kesehatan RI, 1-8.

[2] Ziaeian, B., \& Fonarow, G. C. (2016). Epidemiology and aetiology of heart failure. Nature Reviews. Cardiology, 13(6), 368.

[3] Perhimpunan Dokter Spesialis kardiovaskular Indonesia. (2015). Pedoman Tatalaksanan Gagal jantung. Ed. ketiga. Jakarta: Centra Communications 
[4] Pudiarifanti, N., Pramantara, I. D., \& Ikawati, Z. (2015). Faktor-faktor yang Mempengaruhi Kualitas Hidup Pasien Gagal Jantung Kronik. Jurnal Manajemen dan Pelayanan Farmasi, 5(4), 259-266.

[5] Sulastini, \& Fitria, N. (2016). Hubungan Karakteristik Pasien Dengan Kecemasan Pada Pasien Gagal Jantung Kongestif Di Ruang Rawat Inap Rsu Dr. Slamet Garut.

[6] Susanto, E, Nurkholis 2008, Hubungan Komunikasi Terapeutik Perawat dengan Kecemasan Pasien Gangguan Kardiovaskuler yang Pertama Kali Dirawat dilntensive Coronary Care Unit RSU Tugurejo Semarang, FIK Kes Jurnal Keperawatan, Semarang.

[7] Nugroho \& Aryati. (2014).Hubungan komunikasi terapeutik perawat dengan kepuasan pasien di rumah sakit islam Kendal. Jurnal..unimus.ac.id/index.php/FIKkes/article/view/245/25. 